\title{
Research on Agile English Teaching Based on Constructivism*
}

\author{
Zhao Chun-hui \\ Changchun University, Changchun, China
}

\author{
$\mathrm{Liu} \mathrm{Fu}$ \\ Jilin Jianzhu University, Changchun, China
}

\begin{abstract}
This article is based on fully studying the constructivism theory and the agile software development method which are combined and applied to English teaching; it designs the principle of construction and puts the agile method into English teaching in the frame work of it. Teachers' teaching initiative and innovativeness are mobilized and they are impelled to be active to construct. Students' impetus and confidence in learning English are aroused, and they play the leading roles and are responsible persons in English learning. Teachers interact with students to actively finish the constructing of English learning through teaching. The experimental studies have been made. The examination results, the questionnaire survey, and the targeted interviews demonstrate that the agile English teaching based on constructivism can fully mobilize the enthusiasm of English learning and strengthen self-confidence of English learning, and it has remarkable effect on listening, speaking, reading, and writing. The methods are highly praised and appreciated by the students.
\end{abstract}

Keywords: constructivism, agile method, initiative, experimental studies

\section{Introduction}

English education is an integral part of higher education. It uses English language knowledge and its application skills, learning strategy, and cross-cultural communication as the main content, uses foreign language teaching theory as the guidance, and collects a variety of teaching modes and teaching means for the integration of teaching system. Its teaching goal is to cultivate students' English comprehensive application ability, especially listening and speaking skills. So, students can effectively communicate in spoken and written English in future work and social intercourse, at the same time improve their ability of autonomous learning, and improve their comprehensive cultural quality to adapt to our country's needs of economic development and international exchange. College English comprehensive course, the purpose of which is to improve students' five basic skills-listening, speaking, reading, writing, and translating - has more credits and more tasks. Unfortunately, this subject becomes one of the most disappointing subjects (Cai, 2001, p. 73). Investigating its reasons, the main one is that the network technology is developed, information channels are varied, but the teaching method of "intensive teaching, less practice" cannot meet students' needs in the new period, so there is reform requirement for higher special education teaching.

College English curriculum requirements confirm college English teaching patterns and standards. Teaching methods change from the past single to all-round three-dimensional in classroom teaching, construct

\footnotetext{
* Acknowledgments: This paper is part of the result of the authors' research program "Research on Multimedia Application in English Teaching of Higher Special Education" (2014, No. 276), Jilin Education Department Fund Project, Comparative study of English teaching on the higher special education between China and Japan (S2015022), Chunhui Project of Ministry of Education. Zhao Chun-hui, M.A., associate professor, Public Foreign Language Teaching and Research Department, Changchun University.

Liu Fu, M.A., lecturer, Department of Economics and Management, Jilin Jianzhu University.
} 
research-oriented teaching mode of "taking the students as the main body, teachers as the leading system," promote the college English teaching development in the direction of personalized exploratory learning. Constructivism emphasizes learning as the center, thinks that learning is not to transfer the simple knowledge from the teacher to the students, but learners' individual self knowledge construction process. It highlights the significance of constructing the subjectivity and autonomy of students, makes students change from passive recipients by external stimuli and knowledge objects to subjects and positive constructors who can find information, participate in the main body of information processing actively. And, teachers also change from imparters and instillers of knowledge to the organizers, directors, and helpers of students' learning (Kafai \& Resnik, 1996). But many schools and teachers do not conduct in-depth study and research this theory, only mechanically use it, rely too much on multimedia technology and network technology. The use of information technology in the classroom is not reasonable or even abused. As a result, students fail to improve English learning, the initial inspire learning enthusiasm will gradually weaken (Huang, 2007, p. 21).

Based on the above the background, on the basis of learning theory of constructivism, this paper focuses on intensive researching on English teaching practice, conducting the thorough research on the main ideas, knowledge-based view, epistemology, learning view, conception of teaching, view of teacher, the viewpoint of student, view of environment of constructivism. At the same time, in order to solve the concrete implementation problem of constructivism theory in college English teaching, we conduct interdisciplinary research on agile development thought in computer engineering, then combine constructivism with agile development thought deeply, use agile methods, specifically realize constructivism in foreign language teaching in university, to explore the current path of improvement of the communication ability of college students.

\section{Theoretical Basis}

\section{Constructivism Theory}

Constructivism is based on a famous psychologist J. P. Piaget's structuralism. Piaget thinks "structure" refers to a whole composed of various kinds of transformation rules. It has the characteristics of wholeness transformation and self regulatory; the structure and function are interdependent and interact on each other (Gao, 1999, p. 35). Only under the action of function can structure obtain the continuous development and can be rich. Just in this continuous development, structure changes and updates continuously, evolves finally, this is "constructivism." Constructivism teaching view advocates that under the guidance of teachers, learners are the center and give full play to students' autonomy, teachers are facilitators, organizers, and initiators in the whole teaching environment, not just the provider and instillers of knowledge, students actively take advantage of various of conditions to construct learned knowledge (He, 1997, p. 3).

Constructivism theory rose in the world since the 1990s, around 2000, it was introduced into China, it has comprehensive influence on China's foreign language teaching. Huang and Wang (2007) used statistical method to investigate the present situation of the combination of constructivism with English teaching research in China. Results display that constructivism has been widely applied to every aspect of English teaching in China. At the same time, most study is the combination of constructivism with multimedia network technology, however, empirical research is rare, only $2 \%$.

\section{Agile Based on the Constructivism Teaching Methods}

The core idea of constructivism is that people can not obtain knowledge passively, but build actively 
through the objective subject. Learning is a cycle to assimilate, adapt, assimilate again and then readapt. Adaptation is based on assimilation, unity of assimilation, and adaption is a clear mechanism of knowledge construction. Agile is a people-centered, iteration, and the positive forward method ( $\mathrm{Du}, 2007$, p. 122). Generally speaking, the software development and teaching all belong to the category of management science. By comparing the core idea of constructivism and agile development method, we can find that they are people-oriented, and they all emphasize on iteration and circulation. If teaching and software development can be compared, then students' study and programming can be regarded as equivalent. Teachers are project managers. If agile rapid development process is applied to teaching, quick feedback mechanism and self-commitment mechanism are used to stimulate the learning autonomy and self-responsibility. At the same time, if agile thinking is communicated with each role of teaching, agile teaching method which is based on the constructivism is formed. Constructivism emphasizes on theory, whereas agile methods pay attention to practice. Combining them, they will be in harmony with each other, to be an organic whole. Theory guides practice, practice feeds back theory. Through this kind of interdisciplinary integration, a new road is used to solve the problem of English teaching (Zhang, 2006, p. 153).

\section{Agile English Teaching Design Based on the Constructivism}

Agile English teaching based on constructivism pays attention to the subject position in the process of students' English learning, mobilizes students' initiative of English learning, and emphasizes on ability training. A teacher's responsibility is to fully understand the thoughts of constructivism and agile methods and to apply them to teaching practice, to construct an ideal learning environment (including hardware and software) and to help students fully understand and practice agile English teaching based on constructivism thought, to give students' independency and creativity into full play, and to make them actively build English learning within the group. According to their own ability and level, students make promises, set up reasonable learning goals, make efforts to learn and use English, help each other and improve, increase learning according to agile thought, and finally, realize the independent construction of English learning with differentiated learning.

\section{Conclusion}

Combining good teachers with modern information technology, this is the direction of future development in the construction of the university English course. Constructivism is the theoretical basis to realize this purpose. Under the guidance of this theory, when students learn English, they can change from passive to active, from variable pressure to the power. Under the guidance of this theory, teachers play the "facilitator" role into full play, guide students supplement or extend classroom teaching through the network autonomous learning, make the classroom become teachers-students, students-students living interactive platform. Only in this way can students find their interest in English in the practice, and through active participation in all kinds of activities, construct new system of English language and change the language knowledge into a part of the "self," become meaningful constructivists in the experience, realize oneself in practicing English (Feng, 2006, p. 48).

China is the power country of English learning. Its English learning condition differs in thousands of ways. There is a considerable difference in students' English level. So, the author thinks that in the higher special English teaching in the future, according to the specific situation, we should adjust measures to local conditions, give full play to the advantages of constructivism teaching mode based on agile, and roundly improve students' comprehensive ability. 
In this paper, the main innovation is that the agile English teaching methods based on constructivism, connects English teaching based on constructivism theory with concrete practice combining with agile methods, that is, through specific methods practices constructivism theory, solves the long existing problem of the separation between teaching and scientific research in higher special English teaching, speeds up the transformation of the scientific research achievements in the teaching practice. Through the operation in the study, students' spontaneous interest and their initiative in English learning are improved. Furthermore, students' English listening, speaking, reading, and writing ability and English grades are improved. Students' confidence in learning English is also improved. Students' English learning enters into a virtuous cycle. Foreign teachers' scientific understanding to the nature of teaching and teaching-learning process is enhanced, and research scholar and expert teachers have good development.

\section{References}

Cai, J. G. (2001). Explore college English intensive reading class model. Foreign Language World, 5, 73-78

Du, A. H. (2007). Analysis on college English teaching evaluation mode. Journal of Qinghai Normal University, 1, 122-125

Feng, Y. F. (2006). Constructivism learning design elements should be in English language teaching. Foreign Languages and Their Teaching, 6, 48.

Gao, W. (1999). The features of constructive learning. Global Education, 1, 35-39.

He, K. K. (1997). Model, method and design of constructive learning. Journal of Beijing Normal University, 5, 20.

Huang, H., \& Wang, H. (2007). Survey and thinking on foreign language teaching research in China based on the theory of the constructivism. Foreign Languages and Their Teaching, 6, 21.

Kafai, Y., \& Resnik, M. (1996). Constructivism in practice designing, thinking and learning in a digital world. Mahwah, N.J.: Lawrence Erlbaum Associations.

Zhang, C. S., \& Zhao, T. S. (2006). Unscramble humanism teaching thought. Guangdong: Guangdong Education Press. 